\title{
TOTAL AND MAIN As SPECIES PRESENT IN CARDIOVASCULAR TISSUES OF PEOPLE LIVING IN AS CONTAMINATED AREAS
}

\author{
ISABEL PIZARRO ${ }^{*}$, DOMINGO ROMÁN-SILVA ${ }^{1}$, CARLOS SOLAR ${ }^{2}$, MARÍA MILAGROS GÓMEZ ${ }^{3}$, CARMEN \\ CÁMARA ${ }^{3}$ AND MARÍA ANTONIA PALACIOS ${ }^{3}$
}

\author{
${ }^{1}$ Laboratory of Bioinorganic and Environmental Analytical Chemistry, Department of Chemistry. \\ Faculty of Basic Sciences. Universidad de Antofagasta, Antofagasta (Chile) \\ ${ }^{2}$ Unity of Cardiovascular Surgery. Clínica de Antofagasta, (Chile) \\ ${ }^{3}$ Department of Analytical Chemistry. Faculty of Chemistry. Universidad Complutense de Madrid, (Spain)
}

(Received: January 10, 2012 - Accepted: March 7, 2012)

\begin{abstract}
The concentration levels of As in the Chilean II Region of Antofagasta produces non cancer health outcomes such as cardiovascular diseases and in last term heart attack. On this study, the determination of total As content and main inorganic and organoarsenic species found in three heart tissues (auricle, mammary artery and fat) and the saphene vein of people living in the Chilean II Region, suffering coronary thrombosis has been carried out. Comparison with similar tissues of patients from other non-contaminated areas has been undertaken.

The extraction of As species occurred in methanol: water (1:1) and As species determination have been used the tandem HPLC-ICP-MS using the Hamilton PRP X100 anion column. For total As determination has been performed by HG-AAS and ICP-MS.

The auricle and in less extend the saphene support the higher As concentration (mean values of 7.7 and $2.5 \mu \mathrm{g} \mathrm{g}^{-1}$, respectively), being As(III) the predominant species. Methylarsonate (MA) and dimethylarsinate (DMA) is not a favoured mechanism.

The presence of high total As and high As(III) species content in the auricle and saphene of more contaminated people, the damage found in the saphene tissue and the global characteristics of the people under study in which the As stigmas are present in all of them, suggests that As could be involved in the cardiovascular diseases.
\end{abstract}

\section{INTRODUCTION}

The coastal - Andean Mountain - Upper Highlands Ecosystem of the II Region of Chile is an important area of the Atacama Desert; of which the River Loa basin is a part. This river is an aquatic desert ecosystem, and the source of drinking water for the cities in the II Region of Antofagasta in Chile. However, this particular ecosystem suffers from the chronic impact of endogenous arsenic due to volcanism in the area, and anthropogenic delivery of arsenic and other heavy metal due to mining activity ${ }^{1,6}$, which transport trace elements more rapidly into ecosystem in comparison to the normal geological process, thus spreading the heavy metals to human beings, through the biogeochemical cycles ${ }^{7}$.

It is worldwide known that the Chilean II Region has a heavy concentration of mining activity, related to the copper production and non metallic salts, producing more than two million tons of copper annually ${ }^{8}$ and the well known "nitrato de Chile" from the potassium nitrate mines named "salitreras". The Antofagasta city, in the west - centre of the Region, centralizes the social services and in it outskirts is located some industries related mining. So, the two principal sources of the As impact on the human beings are the As associated to the mineral process which produces As contamination in the zone affecting people directly in some work places, and the As contamination problem from the main water supply. During the period 1950 - 1970, the medium As concentration in drinking water of Antofagasta was about $800 \mathrm{mg} \mathrm{L}^{-19}$. After installation of an As removal plants, the As concentration in drinking water dramatically decreased up to the recommended maximum level of about $50 \mathrm{mg}$ $\mathrm{L}^{-1}$, but fluctuations around this value gives a relatively high As content. In the Chiu-Chiu village without As removal plant, in 1998, drinking water contained $750-800 \mathrm{mg} \mathrm{L}^{-1}$ of As at home ${ }^{10,11}$. At present, the World Health Organization ${ }^{12}$ recommends a guidance value of $10 \mathrm{mg} \mathrm{L}^{-1}$.

The chronic impact of As in the Region produces cancer and non cancer health outcomes ${ }^{13}$. Cancer effects ${ }^{14}$ are in a similar way than in other well documented environmental As exposures of Taiwan ${ }^{15}$, India, Bangladesh, USA ${ }^{16}$, Mexico ${ }^{17}$, Argentina and Hungary ${ }^{18-22}$; different type of cancer, mainly lung and bladder cancer have been reported as main problems As associated diseases. According Smith et al. ${ }^{23}$, the impact of As on the population mortality in the II Region of Chile is greater than that reported anywhere to date from environmental exposure to carcinogen in a major population; dose - response relation between As concentration in well water and mortality from cancers has been characterized ${ }^{12,24}$.
Typical clinical non cancer effects affecting the healthy life quality of the persons, associated with the inorganic As chronic ingestion through drinking water or environmental exposition have been studied and is reported in numerous papers. Vascular diseases, abnormal pigmentation, Raynand's syndrome, acrocyanosis, hyperkeratosis, gangrene of fingers, ischemia of the tongue, diabetes, thrombosis, cerebral vascular disease, especially cerebral infarction, coronary artery occlusions, and other cardiovascular diseases (CVD) has been associated with As exposure ${ }^{10-12,23-28}$. Less common complications such as liver enlargement (hepatomegaly), splenn enlargement (splenomegaly) and fluid in the abdomen (ascitis) also has been cited ${ }^{29}$.

Smoking, high serum low density lipoprotein cholesterol and high blood pressure have been shown to promote atherosclerotic disease in man. Yet these factors explain only about 60 per cent of the incidence of coronary heart disease (CHD) or $\mathrm{CVD}^{30}$. Heart failure is not a uniform disease entity, but a syndrome with various causes, including hypertension, ischemia and congenital heart disease, cardiomyopathy, myocarditis and intoxication ${ }^{31}$. As far as CVD are concerned, there is epidemiological evidence that trace elements may play a role ${ }^{25,32-35}$. However, the overall outcome of the cardiovascular disease epidemiological research has been to confirm the existence of water-related factors, independent of socio-economic or geographical influences on CVD. It has not been possible to identify a specific water constituent as responsible, and there is little hope of doing so by epidemiological research. Also, the nutritional evidence indicates that $\mathrm{Cu}$ is an antioxidant nutrient linked to an impressive array of biological mechanisms associated with CVD, however, most data arise from animal studies where induced copper deficiency was severe ${ }^{36}$. Nevertheless, even more direct evidence respect the trace elements concern is necessary. Accordingly, recently it has been demonstrated that the effect of $\mathrm{Ni}$ on human cardiac tissue was related to oxidative stress ${ }^{37}$. Appear not be apparent that the more direct evidence such as the speciated arsenic status in cardiovascular related tissues should be central to any discussion of trace elements and CVD.

The mechanism across mammalian animals including man metabolises and detoxify inorganic As is methylation to methylarsonate and dimethylarsinate 38. Before this methylation arsenate must be reduced to arsenite; the binding of arsenite to tissue proteins would be an additional or perhaps the first step in the detoxification of inorganic As prior to methylation ${ }^{39}$. Therefore, before methylation, increases the in vivo toxicity and risk to the organism ${ }^{39}$ Otherwise, recently has been informed that biomethylation being a process that potentiates toxicity and carcinogenicity of inorganic $\mathrm{As}^{40}$. 
In autopsy samples of people exposed to environmental basal As levels, the concentration of the element is very similar in all internal organs $(0.1 \mathrm{mg}$ $\left.\mathrm{g}^{-1}\right)$ but slightly higher in hair $\left(0.6 \mathrm{mg} \mathrm{g}^{-1}\right)$ and nails $\left(0.4 \mathrm{mg} \mathrm{g}^{-1}\right)$. However after an acute lethal dose $\left(8.0 \mathrm{~g}\right.$ of $\left.\mathrm{As}_{2} \mathrm{O}_{3}\right)$, the highest levels were observed decreasing order in liver, kidney and other organs (muscle, lungs, brain). The inorganic trivalent species was predominant $(>80 \%)$ and the metabolites MA and DMA represented 10 and 5\% respectively except in lipid rich organs that concentrations of these species are higher ${ }^{41}$. In animals arsenate has been shown to incorporate in the skeleton due to its similarity with phosphate anions. Background levels in breast milk range between 0.1 and $1 \mathrm{ng} \mathrm{L}^{-1}$, but concentrations multiplied by a factor of 4 have been observed in human in case of regular seafood consumption ${ }^{42}$ and by a factor of 8 in case of consumption of drinking water containing $200 \mathrm{mg} \mathrm{As} \mathrm{L}^{-1}{ }^{43}$. Other data indicates that As can easily crosses the animal and human placentas ${ }^{44}$.

The present study deals with the determination of total As content and main inorganic and organoarsenic species found in three heart tissues (auricle, mammary artery and fat) and the saphene vein (used as by-pass) of people chronically exposed to As in the Chilean II Region, suffering cardiovascular diseases (CVD) and subjected to heart surgery in Antofagasta. The found concentrations of total As and As species, and the histology study of some of these tissues, contribute to a best understanding about if As or its main species could be involved in the heart disease.

\section{EXPERIMENTAL}

\section{Instrumentation}

Hydride Generator equipped with an electrothermal mantle GBC EHG3000 and with an As hollow cathode boosted discharge lamp (BDL) from Photron was used to determine the total As content in the Chilean samples.

The Inductively Coupled Plasma Mass Spectrometer (ICP-MS) used for the determination of total As concentrations in samples from persons living in Madrid, and as a detector after HPLC species separation, was an HP - 4500 (Yokogawa Analytical System, Tokio, Japan). This system was fitted with coof a Babington glass nebulizer and a Scott double pass spray chamber. Single ion monitoring at $\mathrm{m} / \mathrm{z} 75$ was used to collect the data. All signal quantification was performed in the peak area mode.

A PRP-X100 analytical and guard anion-exchange column (Hamilton, Reno, NV, USA) were used for HPLC-ICP-MS analysis. The column effluent was directly introduced into the nebulizer via a $250 \mathrm{~mm}$ x $0.5 \mathrm{~mm}$ (id) polytetrafluoroethylene capillary tube.

For chromatographic separations, a HPLC system (LDC Division, Riviera Beach, Florida, USA) was used as a sample pump. Air was removed from the buffers by argon degassing for $15 \mathrm{~min}$ and the buffer was filtered prior to injection. $100 \mu \mathrm{L}$ of samples were introduced through a $0.45 \mu \mathrm{m}$ nylon syringe filter into the injection valve Rheodyne 9125 (USA).

TABLE 1 shows the optimized instrumental parameters for HG-AAS, ICPMS and HPLC system.

\section{Reagents, Standards and Certified Reference Materials}

Sample mineralization were carried out in Teflon reactor bombs placed in usual lab oven and in heating aluminium plate by means a two steps procedure like similar way as Welz and Melcher ${ }^{45}$.

Solvent evaporation of extracts was performed in a Univapo100H-Unijet II system (UNIEQUIP, USA). Sonication of samples was performed in a focused ultrasonic bath (Bandelin Sonopuls HD-2200, Fungilab S.A., USA).

The extracting mixtures were prepared from deionised water (Milli-Q Ultrapure water systems, Millipore, USA) and HPLC-grade methanol (Merck, Darmstadt, Germany). High-purity nitric and hydrochloric acids were obtained by the sub-boiling distillation of the analytical-grade reagent (Merck) in an I.R. distiller (Berghof, BSB-939IR, Germany).

$\mathrm{HF}, \mathrm{HNO}_{3}$ and $\mathrm{H}_{2} \mathrm{SO}_{4}$ acids were Suprapur grade (Merck); $\mathrm{HClO}_{4}$ and $\mathrm{Na}_{2} \mathrm{~S}_{2} \mathrm{O}_{8}$ were Instra grade (J. T. Baker). Other reagents such as $\mathrm{NaBH}_{4}$, $\mathrm{H}_{2} \mathrm{SO}_{4}, \mathrm{NaOH},\left(\mathrm{NH}_{4}\right) \mathrm{H}_{2} \mathrm{PO}_{4}, \mathrm{H}_{3} \mathrm{PO}$, were obtained from Merck. Each arsenic species stock solution containing $1,000 \mathrm{~g} \mathrm{~L}^{-1}$ of As, was prepared by dissolving the respective amount of the pure compounds in water. As(III) and $\mathrm{As}(\mathrm{V})$ standards were prepared from the sodium salt of arsenite and the sodium salt of arsenate obtained from Sigma Aldrich (St Quintin, Fallavier,
France), DMA and MA obtained from Merck, and arsenobetaine (AB) and arsenocholine (AC) obtained from Tri Chemical Laboratory Inc. (Japan). The stock solutions were kept at $4^{\circ} \mathrm{C}$ in the dark. Working solutions were prepared daily and then diluted with water to the final concentration. Three certified from National Research Council Canada (NRCC) reference materials: Luts-1 (non defatted Lobster hepatopancreas), Dorm-1 (Dogfish muscle) and Tort-1 (Lobster hepatopancreas) were used to check the total As determination and also for As species characterisation.

Table 1: Instrumental parameters for total As determination and As speciation analysis.

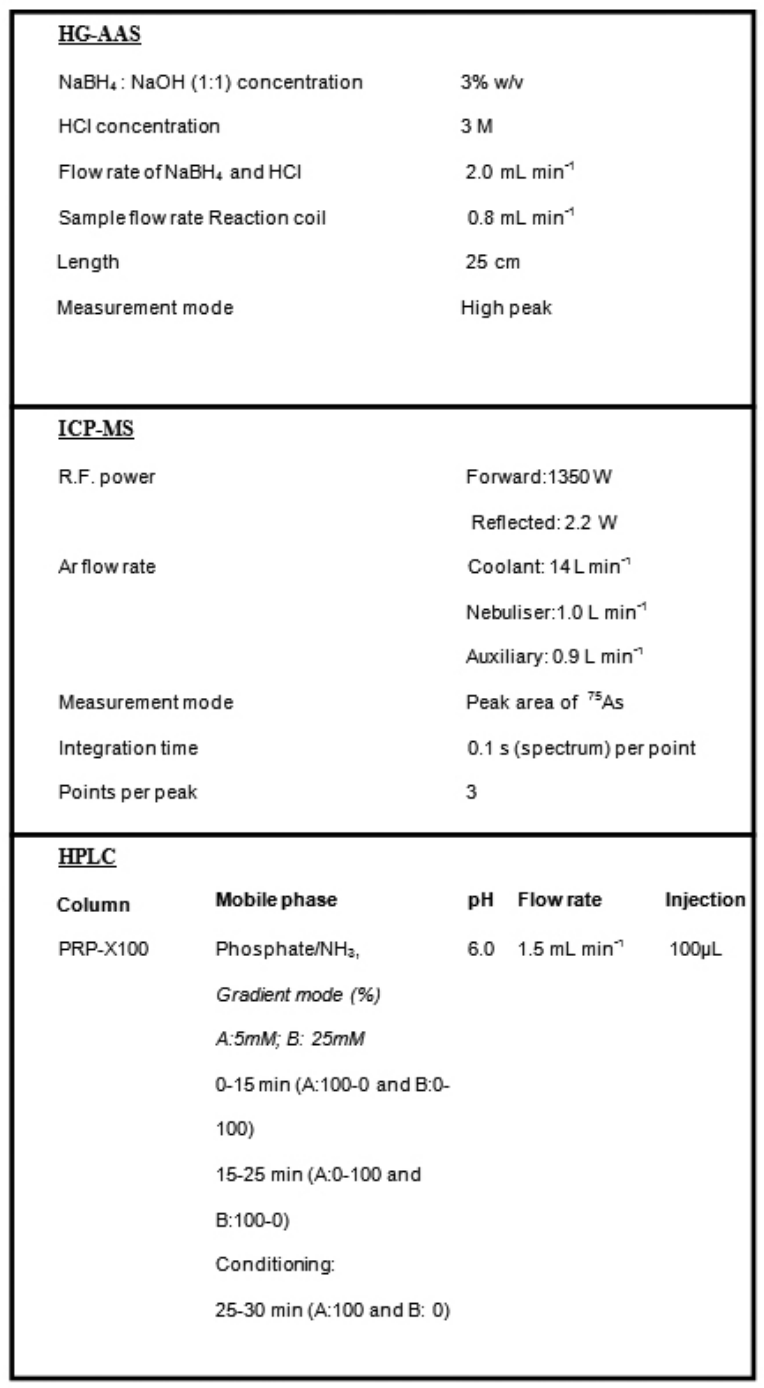

\section{Samples and sample pre treatment}

Auricle tissue, saphene vein, mammary artery and heart fat tissues from about 200 patients operated in the Antofagasta Clinic of coronary thrombosis were analysed for total As content. The samples were obtained from a population under study, made up of patients who have lived at least five years in the II Region of Chile, and population control samples were obtained from patients operated in the Catholic University Clinic in Santiago of Chile, which coming from Chilean Regions without As problem.

All manipulations and procedures for the preparation of the samples were made in the bench of the "clean laboratory" inside a laminar flow hood (Labconco, Purifer Class II) using inert devices such as plastic and Titanium knives, agate grinding mortar, and scalpels, scissors and forceps of surgical stainless steel. In each case, then of be liberated of the Titanium clasp and the fats residues, the tissues were rinsed with deionised water and separated as 
single samples, except the fat of which was prepared as pooled sample. All samples were stored at $-20^{\circ} \mathrm{C}$ before use. Dry weight / wet weight factors were obtained according UNEP protocol for biological tissues ${ }^{46}$.

From these samples, three different groups have been chosen for the study, results presentation and discussion: Group I. More contaminated group formed by 20 people presenting the higher As content in the auricle (the tissue with higher mean As level). Group II. Comparison group formed by 15 people presenting the lower As content in the auricle (probably the heart problem is not due to As); and Group III. Control group formed by 10 people suffering heart attack, which coming from V, VIII and IX Chilean Regions which are not exposed to the impact of arsenic (Valparaiso, Concepción and Temúco). Group IV. An additional samples from similar heart tissues were obtained for basal level from died persons living in Madrid where As contamination is not expected. Before operation, all the Chilean people initially analysed, filled in a survey with some personal characteristics for later relation with the As content.

Table 2: Global characteristics of people under study.

\begin{tabular}{|c|c|c|c|c|}
\hline Population & Region & Type of work & $\begin{array}{c}\text { Age } \\
\text { (years) }\end{array}$ & $\begin{array}{c}\text { As } \\
\text { stigma }\end{array}$ \\
\hline $\begin{array}{c}20 \\
\text { (high As } \\
\text { content) }\end{array}$ & $\begin{array}{c}100 \% \\
\text { Region II. }\end{array}$ & $\begin{array}{c}\text { Mine: } 55 \% \\
\text { Industry: } 40 \% \\
\text { Others }: 5 \%\end{array}$ & 57.2 (mean) & $100 \%$ Yes \\
\hline $\begin{array}{c}15 \\
\text { (low As } \\
\text { content) }\end{array}$ & $\begin{array}{c}100 \% \\
\text { Region II }\end{array}$ & $\begin{array}{c}\text { Industry: } 30 \% \\
\text { Social: } 70 \%\end{array}$ & 56.3 (mean) & $100 \%$ No \\
\hline $\begin{array}{c}100 \% \\
10\end{array}$ & $\begin{array}{c}\text { (Valparaiso } \\
\text { Concepcion } \\
\text { Temúco) } \\
\text { Group) }\end{array}$ & $\begin{array}{c}\text { Social: } 60 \% \\
\text { Agriculture: } \\
4, \text { VIII,IX } \\
\text { Regions }\end{array}$ & 60.0 (mean) & $100 \%$, No \\
\hline
\end{tabular}

\section{Procedures}

\section{Mineralization for total arsenic determination.}

About $0.5-1.0 \mathrm{~g}$ of agate mortar grinded sample were placed in a Teflon reactor bomb ${ }^{45}, 10 \mathrm{~mL}$ of concentrated $\mathrm{HNO}_{3} 2 \mathrm{~mL}$ of concentrated $\mathrm{HClO}_{4}$ and $2 \mathrm{~mL}$ of $2 \% \mathrm{~m} / \mathrm{v} \mathrm{Na}_{2} \mathrm{~S}_{2} \mathrm{O}_{8}$ were added, and the sample was pre-digested overnight at room temperature. Next, the reactor was heated to $150^{\circ} \mathrm{C}$ for 2 hours in an oven. After cooling, $0.5 \mathrm{~mL}$ of concentrated $\mathrm{H}_{2} \mathrm{SO}_{4}$ was added and the digested sample was heated in the heating aluminium plate by semi refluxing in a $50 \mathrm{~mL}$ glass Erlenmeyer flask for about 2 hours (ambient to 300 ${ }^{\circ} \mathrm{C}$ ) until the final volume was about $2 \mathrm{~mL}$. The digested sample was diluted to $10 \mathrm{~mL}$ with $0.5 \mathrm{M} \mathrm{HCl}$ and total As was determined by HG-AAS. When analysis was performed by ICP-MS, distilled water was used for making up to the chosen volumes.

\section{Extraction for As species.}

About $0.5-1.0 \mathrm{~g}$ of tissue materials were placed in plastic centrifuge tubes, and $10 \mathrm{~mL}$ of the methanol-water $1: 1 \mathrm{v} / \mathrm{v}$ mixture was added following similar treatment that performed by Shibata and Morita ${ }^{47}$. The mixture was mechanical shaken for 3 hours, maintained at $55^{\circ} \mathrm{C}$ for 10 hours and finally left in an ultrasonic focalized bath for $5 \mathrm{~min}$. The samples were centrifuged for 15 $\mathrm{min}$ at $6000 \mathrm{rpm}$. After centrifugation, the extract was removed using a Pasteur pipette and the residue was re-extracted using $5 \mathrm{~mL}$ of the same methanolwater mixture under the same operational conditions. The extraction procedure was repeated in the residue once again with a methanol - water mixture 9:1 $\mathrm{v} / \mathrm{v}$ following the procedure formerly described. The methanol - water 1:1 and 9:1 extracts were separately submitted to rotary evaporator at $40^{\circ} \mathrm{C}$ under reduced pressure and a flow of extra pure $\mathrm{N}_{2}$. Each residue were dissolved in adequacy deionised filtered water volumes $(0.45 \mathrm{~mm})$, and kept frozen $\left(-20^{\circ} \mathrm{C}\right)$ prior analysis. Triplicates extracts were prepared from each one cardiovascular tissue sample from the patients in which the arsenic speciation was studied, and each one of the reference material LUTS-1, DORM-1 and Tort-1 for quality control measurements. The general procedure performed is summarized in FIGURE 1

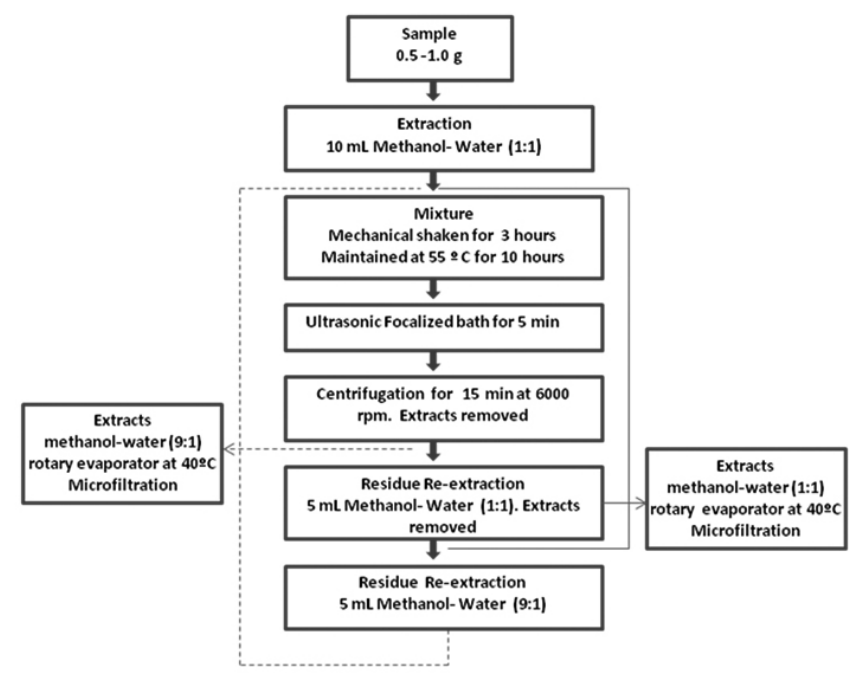

Figure 1: Procedure extraction for As species

\section{Determination of total As.}

Total As content from Chilean people was measured in the samples, extracts and residues (after methanol - water extractions) after mineralization by HG-AAS. The As content in the samples from Madrid (basal level), was measured by ICP-MS. Standard addition calibration was used for HG-AAS. External calibration using As(V) standard solution for ICP-MS was used. ${ }^{72} \mathrm{Ge}$ was used as an internal standard for ICP-MS.

\section{HPLC - ICP - MS for As species}

The extracts methanol-water 1:1 (two consecutive extractions) were diluted with diluted mobile phase solution depending species concentration. A PRP-X100 analytical coupled with a guard anion-exchange column (Hamilton, Reindeer, Nevada, USA) were used for HPLC-ICP-MS hyphenated analysis. For the HPLC chromatographic separations, $100 \mu \mathrm{L}$ of samples were introduced through a $0.45-\mu \mathrm{m}$ nylon syringe filter into the injection valve Rheodyne 9125 (USA) and then pumped into the HPLC system (Milton Roy LDC Division, FL., USA); air was removed from the buffers by argon degassing for $15 \mathrm{~min}$ and the buffer filtered before injection. The column effluent was directly introduced into the nebulizer rod of the ICP-MS equipment by a polytetrafluoroethylene capillary tube of dimension $250 \mathrm{~mm} \times 0.5 \mathrm{~mm}$ (id). The ion intensity at $\mathrm{m} / \mathrm{z}$ of ${ }^{75} \mathrm{As}$ was monitored, but an important interference during ICP-MS analysis is the possible formation of ${ }^{40} \mathrm{Ar}^{35} \mathrm{Cl}$, however chloride concentrations in the analyzed fractions were low and the eventual interference was corrected by the correction factor introduced in the operational software of the instrument. The chromatographic peaks were integrated using the software ICP-MS Plasma Lab and Captures Grams/32 (Galactic Industries Salem NY, USA). An injection of $100 \mu \mathrm{L}$ of $5.0 \mathrm{ng} / \mathrm{mL}$ of ${ }^{75} \mathrm{As}(\mathrm{V})$ was made, along with the internal standard $\left({ }^{72} \mathrm{Ge}\right)$ before each chromatographic run in order to correct drift in the ICP-MS response. TABLE 1 shows the optimized instrumental parameters for the application of the ICP-MS and HPLC techniques.

\section{Analytical validation and traceability of As measurements}

TABLE 3 summarizes the analytic validation data to prove the suitability and efficiency of the described techniques for the determination of As in cardiovascular tissues; i.e. total As, total extracted As with methanol-water 1:1 and 9:1 and the As recovery experiments from the standard reference materials spiked with As species frequently found in biological tissues, such as primary standard of $\mathrm{As}(\mathrm{III})$ and $\mathrm{As}(\mathrm{V})$ from the sodium salt of arsenite and the sodium salt of arsenate; DMA; MA; AB and AC. The SRMs used in these quality control approaches were DORM-1, TORT-1 and LUTS-1. Detection limits were calculated in accordance with IUPAC criteria ${ }^{48,49}$ The results of the measured values of arsenic were accepted if the coefficient variation of the precision and accuracy tests were less to $15 \%$ of the accepted or certified values, respectively.

Before being applied to the cardiovascular tissue samples, the As speciation protocol was applied to samples of standard reference materials (TABLE 3). These results are very similar to those in other reports ${ }^{50-53}$. 
Table 3: Quality control and traceability of the total As concentrations, $\mathrm{MeOH}-\mathrm{H}_{2} \mathrm{O}$ 1:1 fractionated As concentrations and species concentrations of As using standard reference materials (SRM).

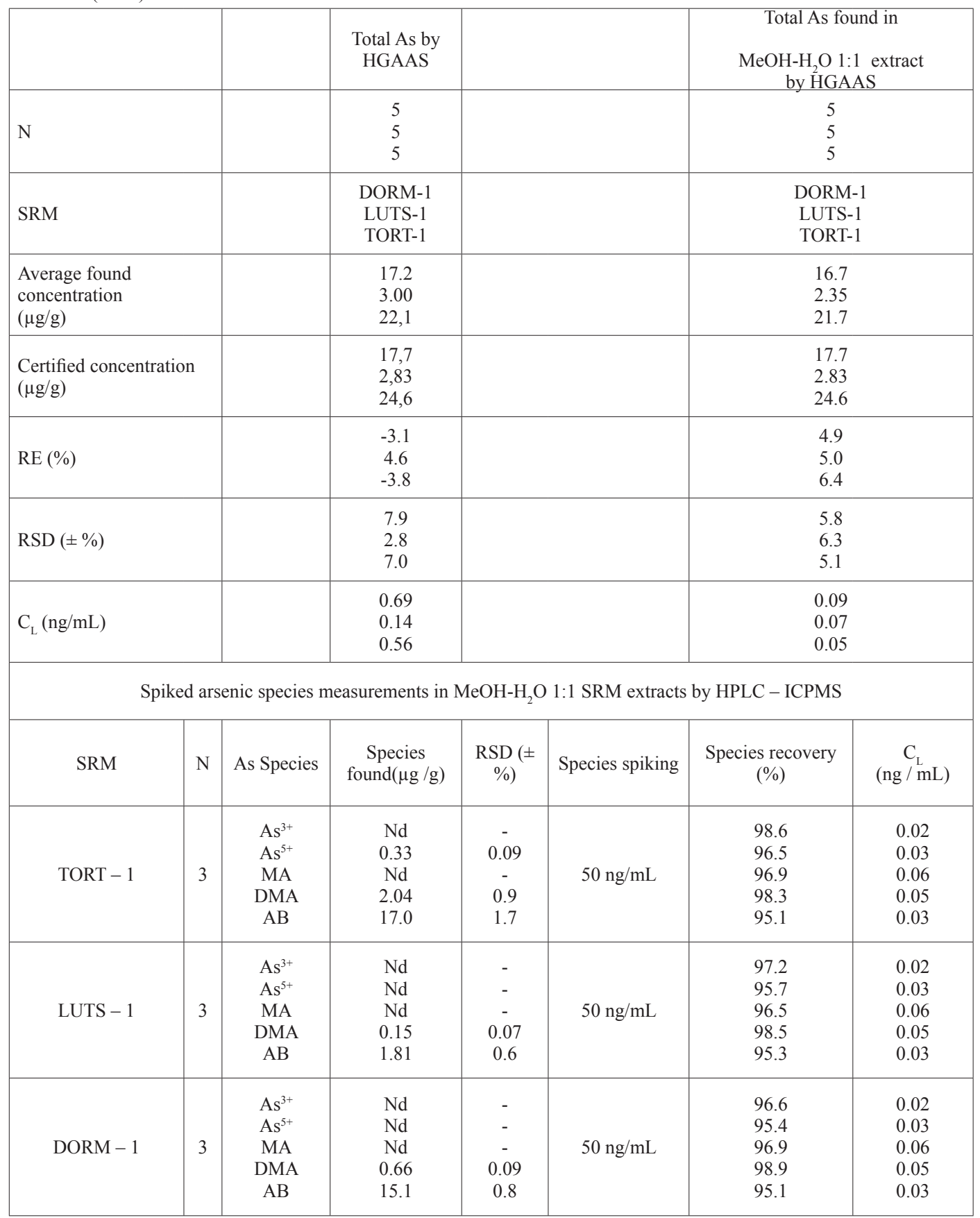

\section{Histological treatment}

For the histological study performed in some samples, the tissue was washed for 24 hours in running water and fixed in paraffin blocks dyed with hematoxilin-eosine, trichromic of Masson and orceine Van Giesson ${ }^{54}$. The histochemical methods its based on combination of chromogenic reagents with mixtures of masking agents that block the reactivity of tissues. The paraffinzed sections show green granules, insoluble in water, through dissolved by acid and by ammonium hydroxide. This procedure demonstrates pretty well every practical histopathologic with additional diagnostic studies such as histological examination in microscopic scission.

\section{RESULTS AND DISCUSSION}

\section{Total As content}

The interval and mean value for total As found in the samples of the four analysed groups are given in TABLE 4. In the Group I (more contaminated), the auricle has by far the higher concentration, with a mean value of $7.7 \mathrm{mg}$ $\mathrm{g}^{-1}$, dry tissue, following by the saphene vein with $2.5 \mathrm{mg} \mathrm{g}^{-1}$. Mamalian artery and fat tissues in this group, present similar but lower As concentration than the former tissues with about $1 \mathrm{mg} \mathrm{g}^{-1}$ each. The total As concentrations found in the auricle (and also saphene) of some people, not chosen as components of the Group I, are really high of about $20 \mathrm{mg} \mathrm{g}^{-1}$ that reveal the high impact of the As in some individuals living and working in the contaminated areas. The comparison (TABLE 4) between Group II (less As contaminated in the Region) 
and Group III, (people from V, VIII an IX Chilean Regions), shows that concentration in the different tissues are quite similar. Considering the long distance between both population groups, these values can be considered as the mean level in these tissues for Chilean people.

Table 4: Concentration intervals and mean value for total As in the analysed tissues for the different analysed groups.

\begin{tabular}{|c|c|c|c|c|}
\hline $\mathbf{N}$ & 3 & 3 & 3 & 3 \\
\hline Tissue & $\begin{array}{l}\text { Group I.(mg g-1) } \\
\text { (high As content) }\end{array}$ & $\begin{array}{l}\left.\text { Group II.(mg g }{ }^{-1}\right) \\
\text { (low As content) }\end{array}$ & $\begin{array}{l}\text { GroupII. }\left(\mathrm{mg} \mathrm{g}^{-1}\right) \\
\text { (control group) }\end{array}$ & $\begin{array}{l}\text { Group IV.(ng g-1) } \\
\quad \text { (basal group) }\end{array}$ \\
\hline Auricle & $\begin{array}{l}7.44-9.4 \\
7.70 \pm 3.85\end{array}$ & $\begin{array}{c}0.79-1.22 \\
1.0 \pm 0.54\end{array}$ & $\begin{array}{c}0.5-1.2 \\
0.90 \pm 0.27\end{array}$ & $32.0 \pm 2.0$ \\
\hline Saphene vein & $\begin{array}{c}1.1-7.7 \\
2.50 \pm 1.64\end{array}$ & $\begin{array}{l}0.26-1.8 \\
0.90 \pm 0.29\end{array}$ & $\begin{array}{c}0.56-1.6 \\
1.0 \pm 0.45\end{array}$ & $\begin{array}{l}\text { (ventricule) } \\
44.0 \pm 3.0\end{array}$ \\
\hline Mammary artery & $\begin{array}{l}1.49-2.18 \\
1.10 \pm 0.39\end{array}$ & $\begin{array}{l}0.12-1.7 \\
0.60 \pm 0,25\end{array}$ & $\begin{array}{c}0.32-1.2 \\
0.8 \pm 0.19\end{array}$ & \\
\hline Fat & $\begin{array}{l}0.40-3.1 \\
1.0 \pm 0.32\end{array}$ & $\begin{array}{l}0.37-1.6 \\
1.70 \pm 0,43\end{array}$ & $\begin{array}{l}0.47-1.5 \\
0.80 \pm 0.32\end{array}$ & \\
\hline
\end{tabular}

However they are quite high comparing the basal level of the whole heart tissue of about $0.003-0.026 \mu \mathrm{g} \mathrm{g}^{-155}$ dry tissue and the Group IV of a person living in Madrid.

\section{Histological study}

FIGURES 2 and 3 shows the histological plates for the saphene of a damaged and non-damaged tissue respectively. The vascular pathology, FIGURE 2, is type concentric intimal fibrosis. This vein-damage consists in the expansion of the internal surface due to miofibroblastos and due to this expand, the light circumference is strongly reduced. In this case, the tissue is seriously ill and the intimal layer has analogous thickness than the muscular layer. The concentric intimal fibrosis does not belong to the principal atherosclerotic disease damage, main causes for heart attack and is produced by age, or by the influence of chemical or immunological processes. In our case, the person is relatively young ( 45 years old) and can be suspected of As as the main cause of the tissue damage. Then, appear not to be apparent that arsenic may cause necrosis in cardiovascular tissues of the man ${ }^{32}$. However, at the light of the new knowledge, a critical issue is how to distinguish between apoptosis and necrosis ${ }^{33}$. The total As concentration found in the saphene of this patient was of $2.1 \mathrm{mg} \mathrm{g}^{-1}$.

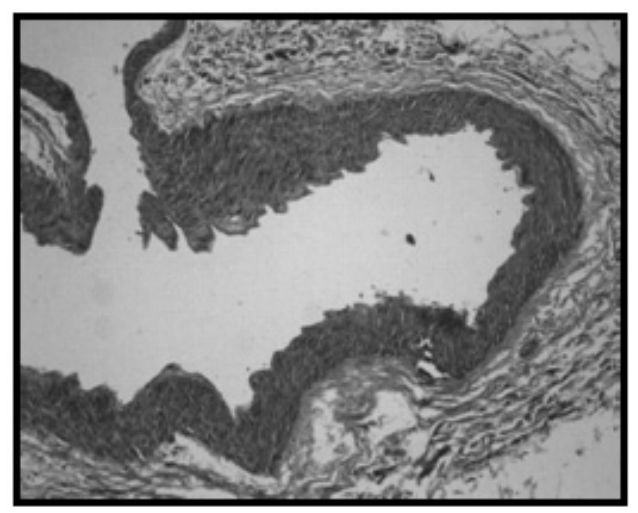

Figure 2: Histological study of a saphene vain suffering concentric a intimal fibrosis.

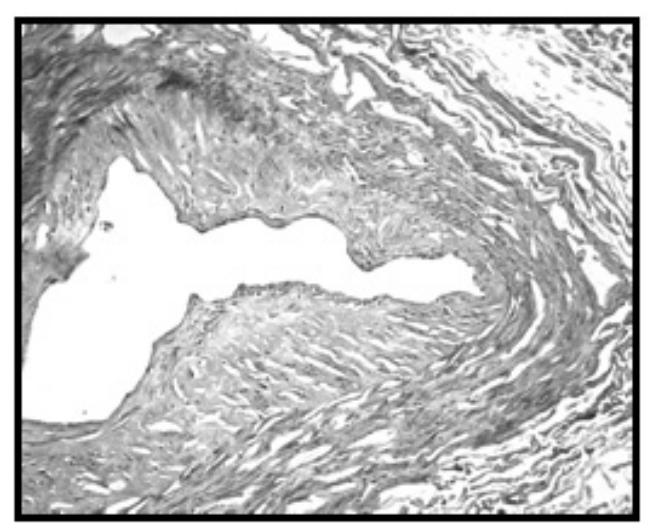

Figure 3: Histological study of a normal saphene vein.

As species found in the different analysed tissues.

Six species were considered for As speciation in the tissues. As(III) and $\mathrm{As}(\mathrm{V})$ because they are the main contaminant species. MA and DMA because both are the main products of the cellular biomethylation through the conjugated effects of S-adenosylmethionine and the methyltransferase enzyme. Arsenobetaine (AB) and arsenocholine (AC) because they can enter the human organism through food, mainly of marine origin.

The four tissues (auricle, saphene, mammary artery and fat) of some people from the Group I has been analysed for As species.

TABLE 5 contains the total As concentration, extraction efficiency on methanol-water 1:1 (two consecutive extractions), and methanol water 9:1 (after the two first extractions) in the above cellular residue, and \% of non extracted As retained in the cellular residual material. 
Table 5: Fractionation of total As concentration ( $\mu \mathrm{g} \mathrm{g}^{-1}$ dry weight) in cardiovascular tissues expressed in extraction efficiency (\%) on methanol-water 1:1, and methanol water 9:1 (see text) and \% of non extracted As on the residue. $\mathrm{Nd}=$ no detected.

\begin{tabular}{|c|c|c|c|c|}
\hline $\mathrm{N}$ & Auricle 3 & Mammary artery 3 & Saphenous vein 3 & Fat tissue 3 \\
\hline Total As $(\mu \mathrm{g} / \mathrm{g})$ & $6.9 \pm 2.1$ & $0.9 \pm 0.2$ & $4.96 \pm 1.2$ & $0.8 \pm 0.2$ \\
\hline \multicolumn{5}{|c|}{$\begin{array}{l}\text { Fractionation and chromatographic arsenic speciation. } \\
\mathrm{MeOH}-\mathrm{H}_{2} \mathrm{O}(1: 1) \quad \text { Extraction efficiency }\end{array}$} \\
\hline $\begin{array}{c}\text { Total As } \\
\mathrm{As}^{3+} \\
\mathrm{As}^{5+} \\
\text { MA } \\
\text { DMA } \\
\text { AB }\end{array}$ & $\begin{array}{c}70.9 \pm 3.1 \\
42.4 \pm 2.3 \\
6.8 \pm 1.5 \\
\mathrm{Nd} \\
\mathrm{Nd} \\
\mathrm{Nd}\end{array}$ & $\begin{array}{c}60.3 \pm 2.7 \\
\mathrm{Nd} \\
29.8 \pm 2.6 \\
3.8 \pm 0.9 \\
6,2 \pm 1.9 \\
18.8 \pm 2.4\end{array}$ & $\begin{array}{c}56.2 \pm 2.9 \\
30.1 \pm 3.2 \\
4.4 \pm 1.2 \\
\mathrm{Nd} \\
3.1 \pm 1.5 \\
\mathrm{Nd}\end{array}$ & $\begin{array}{c}67.4 \pm 2.9 \\
\mathrm{Nd} \\
21.5 \pm 2.5 \\
\mathrm{Nd} \\
5.8 \pm 1.9 \\
33.9 \pm 2.9\end{array}$ \\
\hline $\begin{array}{l}\mathrm{MeOH}-\mathrm{H}_{2} \mathrm{O}(9: 1) \\
\text { Total As }\end{array}$ & $19.3 \pm 2.0$ & $\begin{array}{c}\text { Extraction efficiency (\%) } \\
26.2 \pm 2.5\end{array}$ & $29.7 \pm 2.9$ & $30.3 \pm 2.2$ \\
\hline Residual As \% & $9.1 \pm 1.8$ & $12.0 \pm 1.1$ & $12.2 \pm 1.3$ & $1.9 \pm 0.7$ \\
\hline
\end{tabular}

TABLE 5 shows the results of the As fractionation in methanol-water mixtures 47 and the IC-HPLC-MS chromatographic speciation of the cardiovascular tissues. These results show that most of the As in the tissues examined was extracted by the 1:1 and 9:1 methanol-water-extracting solutions; this has also been observed in other biological tissues ${ }^{47}$. Under these conditions, the As species contained in these cells could be extracted and the As speciation investigated. Most of the total As concentrations were extracted in 1:1 methanol-water-extracting solution, so we can assume that at least the 1:1 methanol-water extract contains the As species of the cytosol solution.

FIGURES 4 (a-e) shows the chromatograms of the species of mixture of As species containing $15 \mathrm{mg} \mathrm{L}^{-1}$ of $\mathrm{AB}$ and $5 \mathrm{mg} \mathrm{L}^{-1}$ of the other As species and As species content in the methanol-water extract of a person of Group I, and the after one methanol water 1:1 extraction. FIGURES $5(a-d)$, shows the percentage of each of the present species of this person. Similar chromatograms and species were obtained for other people in this group (not shown).

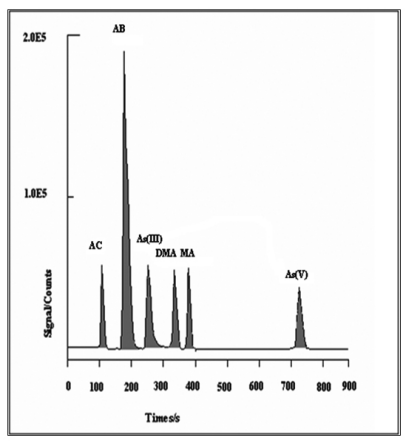

(a) Standard of As species containing $15 \mathrm{mg} \mathrm{L}^{-1}$ of $\mathrm{AB}$ and $5 \mathrm{mgL}^{-1}$ of the others As species

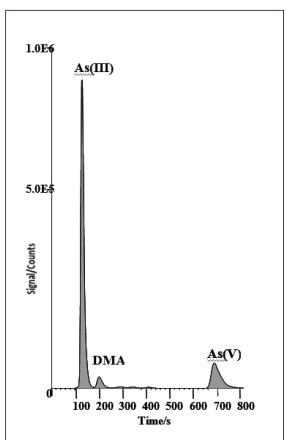

(c) Saphene

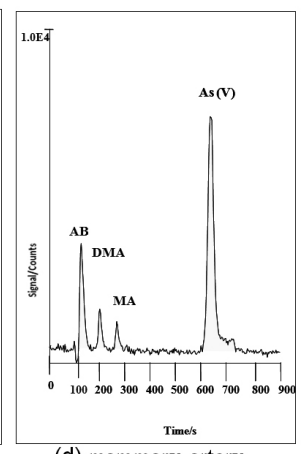

(d) mammary artery

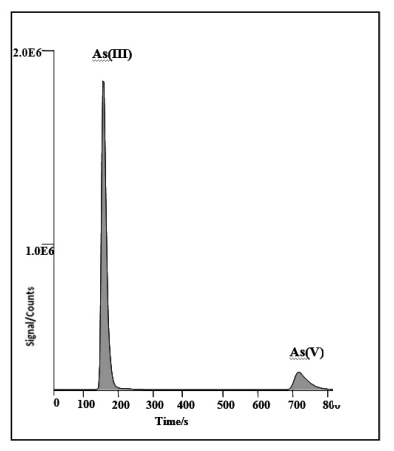

(b) Auricle
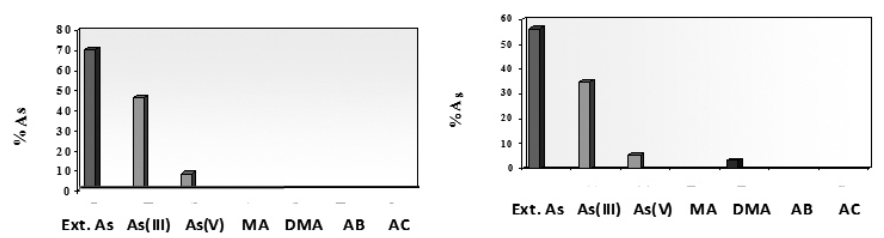

C)

Fat

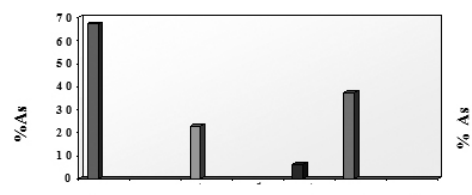

Ext. As As(III) As(Y) MA DMA AB AC b) Saphene d) Mammary Artery

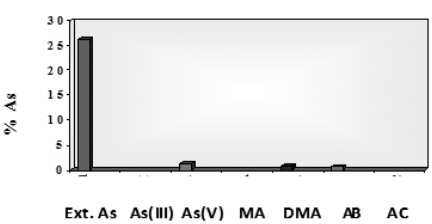

Figure 5: Percentage of As extraction and As species referred to dry tissue for: (a) auricle, (b) saphene, (c) fat and (d) mammary artery tissues after methanol-water 1:1 extraction.

First of all it is important to point out that most of the As present in all the tissues is extracted in the methanol-water 1:1 extract, TABLE 5. Methanolwater 9:1 extract coming from the cellular residues resulted be the preferred medium for organoarsenic compounds, but more works are in progress to this respect.

From FIGURES ( $4 b$ and $5 a$ ), can be seen that in the case of auricle, only $\mathrm{As}(\mathrm{III})$ and $\mathrm{As}(\mathrm{V})$ are the species present in the tissue. After the first methanolic extraction which contain to the cytosol solution, the As(III) extracted was about $50 \%$ of the total As content in the tissue. The $\mathrm{As}(\mathrm{V})$ is about $10 \%$ of the total. This result is interesting because $\operatorname{As}(\mathrm{V})$ is the main contaminant species present in the natural waters, therefore biotranformation to $\mathrm{As}(\mathrm{III})$ is a main mechanism. Not other species seems to be present. Both inorganic As species were confirmed by spiking with standard solutions of the species. Completely symmetrical increases of the peaks were obtained. As(III) was also characterised using the cationic column Hamilton PRP X200 (Mobile phase $4 \mathrm{mM}$ pyridine/formiate, $\mathrm{pH} 2.8$ mode isocratic,chromatograms not given) in which As(III) is not overlapped with other possible species.

In the saphene vein also $\mathrm{As}(\mathrm{III})$ and $\mathrm{As}(\mathrm{V})$ are the main species present, but little amount of other species such as DMA was found. One again the As(III) is the predominant species in the methanolic extract, which could involve that free As(III) specie is a principal component of the cytosol solution in this cardiovascular tissues.

In fat tissue $\mathrm{AB}$ is the predominant species and in the mammary artery the $\mathrm{As}(\mathrm{V})$ species, that account about $40 \%$ and $30 \%$ respectively of the total As extraction. 
content in the respective tissues. Both As species were confirmed by spiking with standard solutions of the species. Completely symmetrical increases of the peaks were obtained. $\mathrm{AB}$ was also characterised using the cationic column Hamilton PRP X200 (Mobile phase 4mM pyridine/formiate, pH 2.8 mode isocratic, chromatograms not given) in which $\mathrm{AB}$ is not overlapped with other possible species. The arsenic species stability was also monitored during sample preparation and storage ${ }^{56}$.

Dorm-1 and Tort- 1 species have also been quantified and although only total As is certified in both materials, our species concentration are close to the reported in others works ${ }^{50-53}$. Our results were in $\mathrm{mg} \mathrm{g}^{-1}$, for Dorm-1: AB (15.0), and DMA (0.54), and the reported paper from others ${ }^{50-53}$ are $\mathrm{AB}(15.5$ -14.1) and DMA (0.60). For the Tort-1 material, we found AB (15.3), DMA $(1.41)$ and $\mathrm{As}(\mathrm{V})(0.30)$ and $\mathrm{AC}(\mathrm{Nd})$, and the reported results were: $\mathrm{AB}(16.0)$ , DMA (1.64, and 1.01), AC ( 0.04), and As(V) $(0.39)^{57-59}$.

\section{CONCLUSIONS}

It is known that inorganic As species have a high affinity for proteins containing conjugated sulphur groups and therefore extracellular and intracellular proteins could bind As. Although inorganic As(III) is the main species bounded to proteins, some other studies report, for example, that in the rat liver intracellular solution, about one half of the methylated As species were protein bound ${ }^{60}$. Treatments such as precipitation of proteins with $5 \%$ trichloroacetic acid, thiol - reactive agents (ex. N-ethylmaleimide, b-mercaptoethanol) or chelators ( ex. 2,3 dimercaptopropanol) failed to release most protein-bound to arsenicals. Treatment with $\mathrm{CuCl}$ releases about $90 \%$ of all protein-bound arsenicals ${ }^{61}$. The fact that the methanol - water 1:1 and 9:1 extracting solutions yield higher than $80 \%$ of As species in most of the biological samples and also in the heart tissues analysed in this work, suggest that intracellular As species can be extracted in these extracting mixtures.

Transporters as carrier proteins, channels and ion pumps have all been regarded as mechanisms that are capable of permitting the movement of ions across the cell membranes by both electrochemical gradient and the different composition of intracellular and extra cellular fluids ${ }^{62}$.

One surprising fact is that the DMA and MA species are absent in the auricle tissue and the concentration of DMA is very low in the saphene vein in Group I, mostly considering that these species are the main species formed in the detoxification mechanism. Some explanation can be highlighted: i) the lack of methylation mechanisms because of the lack of methylating agents in these tissues; ii) at a certain inorganic As dose level, the methylation efficiency decreases in animals and humans ${ }^{61}$; iii) the incapability of DMA to bind some cell constituents as in the case of lungs of rabbits has been found ${ }^{63,64}$.

The presence of high total As and high As(III) species content in the auricle and saphene of more contaminated people (Group I), the damage found in the saphene tissue and the global characteristics of the people under study in which the As stigmas are present in all of them, suggests that As could be involved in the cardiovascular diseases (CVD).

Additional studies to know the association between As species and proteins are now in progress.

\section{ACKNOWLEDGEMENTS}

This research was supported by a grant under the EU's RTD programme and the BQU 2002-01348 project, and resources through Universidad de Antofagasta Asistencia Técnica to one of us (DARS).

\section{REFERENCES}

1. H. Niemayer, Estudio de la contaminación del Río Loa. Ministerio de Obras Públicas y Transportes, Dirección de Riego, 1967;1 - 44

2. J. Narváez, P. Richter, M. I. Toral, J. Chil. Chem. Soc. 52, 1261,(2007)

3. V. Herrera, I. De Gregori, H. Pinochet, J. Chil. Chem. Soc. 54, 282,(2009)

4. F. Queirolo, S. Stegen, C. Contreras - Ortega, P. Ostapczuk, A. Queirolo, B. Paredes, J. Chil. Chem. Soc. 54, 464,(2009)

5. O. Muñoz, P. Díaz, I. Leyton, N. Núñez, V. Devesa, R. Montoro, J. Agric. Food Chem. 50, 642, (2002)

6. D. Román - Silva, L. Rivera, T. Morales, J. Ávila, P.Cortés, Intern. J. Environ. Anal. Chem. 83, 327, (2003)

7. V. Novodny, Diffuse sources of pollution by toxic metals and impact on receiving waters, In: Heavy Metals. Problems and Solutions. (W. Salomons, U. Förstner and P. Mader Editors), Springer, Berlin, 1995, pp. $33-64$

8. J. A. Correa, M. A. Ramírez, J.-P. De La Harpe, D. Román, L. Rivera, Env. Mon. Assess. 61, 265, (2000)

9. C. Ferrecio, P.C. Gonzalez, S. V. Milosavjlevic, G.G. Marshall, A.M. Sancha, Cad. Saude Publica 14, 193, (1998)

10. I. Herts-Picciotto, H.M. Arrighi, S.W. Hu, Am J Epidemiol, 151, 174, (2000)

11. H.Y. Chiou, Y.M. Hsueh, K.F. Liaw, S.F. Horng, M.H. Chiang, Y.S. Pu, J.S.N. Lin, Ch.H. Huang, Ch. J. Chen, Cancer Res. 55, 1296, (1995)

12. WHO (2008). Guidelines for drinking-water quality, 3rd edition incorporating 1st and 2nd addenda. Vol. 1. Geneva, World Health Organization, pp. 306-308b

13. U. S. A. National Research Council. Arsenic in Drinking Water. National Academy Press, Washington D. C. 1999; $1-310$

14. R. Zaldivar, L Prunes, G. L. Ghai, Arch. Toxicol. 47, 145, (1981)

15. C.J. Chen, Y.C. Chuang., T.M. Lin., H.Y. Wu, Cancer Res. 45, 5895 , (1985)

16. A.H. Smith, C. Hopenhayn - Rich, M. N. Bates, H. M. Goeden, I. HertzPicciotto, H.M. Douglas, Environ. Health Perspect. 97, 259, (1992)

17. M.E. Cebrian, A. Albores, M. Aguilar Blakey, Toxicol. 2, 121, (1983)

18. J.H Lubin, J.F. Fraumeni, Am. J. Epidemiol. 152, 290, (2000)

19. U. Chowdhury, D. Chakraborti, G. Samanta, K. Mandal, C. R. Gautan Chitta, Environ. Health Perspect. 108, 393, (2000)

20. M. Col, C. Col, A. Soran, B. Sayli, Environ. Health Perspect. 107, 687, (1999)

21. M. Wu, T. Kuo, Y. Hanhwang, Ch. Chen, Am. J. Epidemiol. 130, 1123 (1989)

22. U.S. EPA. Drinking water Regulations and Health Advisories Washington, DC. U.S. Environmental Protection Agency, Health and Ecological Criteria Division 1993

23. A. H. Smith, M. Goycolea, R. Haque, M. Biggs, Am. J. Epidemiol.147, 660, (1998)

24. R. R. Engel, C. Hopenhayn-Rich, O. Receveur, A. H. Smith, Epidemiol. Rev. 15, 184, (1994)

25. R. R. Engel, A. H. Smith, Arch. Environ. Health, 49, 418, (1994)

26. S. Wang, J. Chiou, Ch. Cheng, Ch. Tseng, W. Chou, C. Wang, Environ. Health Perspect. 111, 155, (2002)

27. J. A. Centeno, F. G. Mullik, L. Martínez, N. P. Page, H. Gibb, C. Longfellow, Environ. Health Perspect.110, 883, (2002)

28. M. Lee, B. Jung, S. Chung, O. Bae, J. Lee, J. Park, Environ. Health Perspect.111, 513, (2003)

29. C. Hopenhayn-Rich, S. Browning, I. Hertz, C. Ferrecio, H. Gibb, Environ Health Perspect.; 108, 667, (2000)

30. J. Virtamo, J. K. Huttunen, Ann. Clin. Res. 20, 102, (1988)

31. D. Jäger, P. R. Jungblut, U. Müller, J. Chromatogr. B. 771, 131, (2002)

32. R. Masironi, Bull. Wld. Hlth. Org. 40, 305, (1969)

33. Y. J. Kang, Environ. Health Perspect. 109, 27, (2001)

34. H. Boström, P. O. Wester, Acta Med. Scand.181, 465, (1967)

35. R. Masironi, A.T. Miesch, M. D. Crawford, E.I. Hamilton, Bull. Wld. Hlth. Org. 47, 139, (1972)

36. $\mathrm{N}^{\circ}$ 54, pp 127 - 140. B. Sandstrôm and P. Walter eds., Karge. Basel, Switzerland

37. E. Novelli, Y. Diniz, J. T. Almeida Machado, V. Proenca, T. Tibiricá, Toxic Sub. Mech. 19, 177, (2000)

38. J.P. Buchet, R. Lauwerys, H. Roels, Int. Arch. Occup. Environ. Health 48,111, (1981)

39. G. Bogdan., A. Sampayo, H. Vasken, Toxicology 93, 175, (1994)

40. M. Stýblo, Z. Drobna, I. Jaspera, S. Lin, D. J. Thomas, Environ. Health Perspect. 110, 767, (2002)

41. J.H. Farmer, L.R. Johnson, Brit. J. Med. 47, 342, (1990)

42. P. Grandjean, P.Weibe, L. Needham, V. Burse, D. Patterson, E. Sampson. Environ. Res. 71, 29, (1995)

43. G. Concha, D. Vogler, B. Lezeano, M. Vahter, Toxicol. Sci. 44, 185, (1998)

44. In: Toxicology of Metals. 1996 L.W. Chang, T. Suzuki eds. Lewis Pub. Boca Raton, Florida pp. $1003-1026$

45. B Welz, M. Melcher, Anal Chem 57, 427, (1985)

46. United Nations Environmental Program (UNEP). Determination of Total Selenium in Selected Marine organisms by Hydride Generation Atomic Absorption Spectrometry. Reference Method for Marine Pollution Studies No 10,1984 
47. Y. Shibata, M. Morita, Appl. Organomet Chem. 6, 340, (1992)

48. G.L. Long, J.D. Winefordner, Anal. Chem. 13, 712, (1983)

49. L.A. Currie. Anal Chim Acta, 391, 105, (1999)

50. D. Beauchemin, M.E. Bednas, S.S. Berman, J.W. McLaren, K.W.M. Siu, R.E. Sturgeon. Anal. Chem. 60, 2209, (1988)

51. I. Serafimovski, I. Karadjova, T. Stafilov, D. Tsalev. Microchemical Journal, 83, 55, (2006)

52. Y. Shibata, M. Morita. Anal. Chem. 61, 2116, (1989)

53. P.A. Gallagher, S. Murray, X. Wei, C.A. Schwegel, J.T. Creed. J. Anal. At. Spectrom. 17, 581, (2002)

54. P. Rippstein, M. K. Black, M. Boivin, J. P. Veinot, X. Ma, Y. X. Chen, P. Human, P. Zilla, E. R. O’Brien, J. Histochem Cytochem 54, 673, (2006)

55. J. Castro. Acta Bioquímica Clínica 17, 3, (1995)
56. I. Pizarro, M. Gómez, C. Cámara, M.A. Palacios, Anal. Chim. Acta, 495, 85 ( 2003)

57. K. J. Lamble, S. J. Hill, Anal. Chim. Acta, 334, 261,(1996)

58. J. L. Gómez-Ariza, D. Sánchez-Rodas R. Beltrán, I. Giráldez, Intern. J. Environ. Anal. Chem. 74, 203, (1999)

59. J. L. Gómez-Ariza, D. Sánchez-Rodas, I. Giráldez, E. Morales, Talanta, 51, 257,(2000)

60. M. Stýblo, M. Hughes, D. Thomas, J. Chromatogr. B 677, 161,(1996)

61. C. Hopenhayn - Rich, A. H. Smith, H.M. Goeden, Environ. Res 60,161,(1993)

62. R. J. Williams, J. J. Frausto da Silva, Coord. Chem. Rev. 202, 247, (2000)

63. F. Bertolero, E. Marafante, R. Pietra, E. Sabbioni, Toxicology 20,35,(1981)

64. E. Marafante, M.Vahter, J. Envia, Chem. Biol. Interact. 56, 225,(1985). 